\title{
Pengembangan modul biologi materi pokok ekosistem berbasis aktivitas siswa di pondok pesantren untuk menanamkan sikap spiritual dan kemandirian siswa
}

\author{
Nunung Susanti ${ }^{1}$ *, D. Djukri ${ }^{2}$ \\ ${ }^{1}$ Madrasah Aliyah Ibnul Qoyyim Sleman. Jalan Jogja-Wonosari Km 8,5 Berbah Sleman, Indonesia \\ ${ }^{2}$ Program Studi Pendidikan Biologi, Program Pascasarjana, Universitas Negeri Yogyakarta. \\ Jalan Colombo No. 1, Karangmalang, Yogyakarta, 55281, Indonesia. \\ * Corresponding Author: noenkzuliyadi@yahoo.com
}

Received: 19 October 2015; Revised: 11 April 2018; Accepted: 3 May 2018

\begin{abstract}
Abstrak
Penelitian ini bertujuan untuk mengembangkan modul biologi berbasis aktivitas siswa di pondok pesantren yang efektif untuk meningkatkan sikap spiritual dan kemandirian siswa. Penelitian ini adalah penelitian pengembangan produk yang mengadaptasi model Borg dan Gall. Langkah-langkah yang dilakukan yaitu tahap pencarian dan pengumpulan informasi, perencanaan, pengembangan draf produk, uji coba lapangan awal, merevisi hasil uji coba awal, uji coba lapangan produk utama, dan revisi hasil uji coba produk utama. Subjek penelitian adalah siswa kelas X Madrasah Aliyah Ibnul Qoyyim Sleman. Data yang dikumpulkan berupa hasil penilaian modul, sikap spiritual, dan kemandirian siswa. Instrumen yang digunakan adalah: lembar validasi modul dan observasi kemandirian, angket keterbacaan modul, respon siswa, penilaian diri sikap spiritual, dan kemandirian. Hasil penelitian adalah: (1) produk modul yang memenuhi kriteria sebagai bahan ajar dengan kategori nilai sangat baik (A), (2) modul efektif untuk meningkatkan sikap spiritual siswa dengan kategori tinggi (gain score 0,81 ) dan meningkatkan kemandirian siswa dengan kategori sedang ( gain score $0,52)$.
\end{abstract}

Kata Kunci: kemandirian, modul, sikap spiritual

\section{Developing a biology module in ecosystem subject based on student's activity at islamic boarding school to inculcate the spiritual attitude and self-reliance of students}

\begin{abstract}
This research aims to develop a qualified biology module based on student's activity in Islamic boarding school to improve students' spiritual attitude achievement and students' self-reliance. This research was research and development adapting Borg and Gall model. The stages of the research were research and collecting information, planning, developing a preliminary draft product, preliminary field testing, main product revision, main field testing, and operational product revision. The research subject were students of class X Madrasah Aliyah Ibnul Qoyyim Sleman. The data were collected in the form of module assessment results, students' self-reliance and students' spiritual attitudes achievement. The research instruments were a sheet of module validation and self-reliance, a questionnaire of module readability, students' responses, self-reliance, and self-assessment to spiritual attitude. The results of this research are: (1) a biology module based on Islamic boarding school which is qualified and feasible to apply as teaching material with a very good category (A), (2) module is effective to improve the spiritual attitude in high category (gain score 0.81)and of the students students' self-reliance in middle category (gain score 0.52).
\end{abstract}

Keywords: self-reliance, module, spiritual attitude

How to Cite: Susanti, N., \& Djukri, D. (2018). Pengembangan modul biologi berbasis pondok pesantren untuk menanamkan sikap spiritual dan kemandirian siswa. Jurnal Inovasi Pendidikan IPA, 4(1), 64-74. doi:http://dx.doi.org/10.21831/jipi.v4i1.5995

http://dx.doi.org/10.21831/jipi.v4i1.5995 


\section{Jurnal Inovasi Pendidikan IPA, 4 (1), 2018 - 65}

Nunung Susanti, D. Djukri

\section{PENDAHULUAN}

Baik Kurikulum 2006 maupun Kurikulum 2013 mengamanatkan pembelajaran yang tepadu agar pembelajaran menjadi lebih bermakna. Kurikulum 2006 sudah mengembangkan pengetahuan, keterampilan dan sikap melalui penjabaran Standar Kompetensi (SK) dan Kompetensi Dasar (KD), sedangkan Kurikulum 2013 mengembangkan pembentukan sikap, keterampilan dan pengetahuan melalui Kompetensi Inti (KI) dan Kompetensi Dasar (KD). Berdasarkan hal tersebut seharusnya pembelajaran harus bisa mengembangkan tiga aspek yaitu sikap, keterampilan, dan pengetahuan.

Sugiarto \& Djukri (2015, p. 3) menyebutkan bahwa pembelajaran di sekolah umumnya belum mengacu pada meaningful learning. Pembelajaran seharusnya bermakna tidak hanya secara teoritis, tapi harus mampu mengaitkan pembelajaran di kelas dengan kehidupan seharihari di dunia nyata. Sekolah sebagai lembaga pendidikan seharusnya harus memfasilitasi peserta didik dalam pencapaian kompetensi sekaligus melatihkan penerapan pembelajaran dalam kehidupan nyata. Hal itu sesuai dengan pendapat Crawford \& Rossiter (1991, p. 49) menyatakan bahwa sekolah harus mempersiapkan siswa untuk menerima tanggungjawab sosial sebagai anggota masyarakat yang demokratis. Untuk itu siswa harus belajar pengetahuan, mengembangkan keterampilan, nilai dan sikap yang akan berguna bagi mereka saat bermasyarakat.

Pembelajaran Biologi yang merupakan bagian dari Ilmu Pengetahuan Alam (IPA) juga bertanggungjawab terhadap pengembangan tiga ranah sesuai arahan kurikulum. Hal tersebut sesuai dengan karakeristik IPA menurut Chiappetta \& Koballa (2010, p. 105) dalam sains terdapat empat dimensi yang dikembangkan yaitu: (1) Science as a way of thinking (sains sebagai cara berpikir) yang berarti untuk mempelajari sains diperlukan sikap ilmiah, yaitu sikap yang mendukung dalam pembelajaran sains, diantaranya: keyakinan, rasa ingin tau, imajinasi, penalaran, kritis, berpikian terbuka dan objektif; (2) Science as a way of investigating (sains sebagai cara investigasi) yang berarti sains adalah sebuah metode untuk menyelidiki sesuatu. Metode ini sering disebut metode ilmiah yang terdiri atas 5 langkah, yaitu: observasi, mengumpulkan data/informasi, membangun hipotesis, melakukan eksperimen, dan menyimpulkan; (3) Science as a body of knowledge (sains sebagai kumpulan pengetahuan); dan (4)

Science and its interactions with technology and society (sains dan interaksinya terhadap teknologi dan masyarakat). Perkembangan sains tidak pernah lepas dari peran masyarakat dan teknologi. Ketiganya saling mempengaruhi.

Kondisi di lapangan terutama pada madrasah umumnya pembelajaran biologi masih menekankan pada penguasaan pengetahuan saja. Pengembangan sikap spiritual di madrasah umumnya masih menjadi tanggung jawab mata pelajaran agama atau mapel serumpun seperti Aqidah-Akhlak, Fikih, dan Al Qur'an Hadist. Mata Pelajaran Umum misalnya Biologi, Fisika, Kimia, Ekonomi masih sangat sedikit berkontribusi terhadap pembentukan sikap tersebut. Padahal menurut kurikulum 2013, sikap spiritual ini menjadi tanggung jawab semua mapel, sehingga peserta didik dapat mengimplementasikannya dalam kehidupan sehari-hari.

Berdasarkan pengamatan di lapangan, pembelajaran Biologi belum berkontribusi aktif terhadap pembentukan dan pengembangan sikap spiritual, padahal pembelajaran Biologi mempunyai objek berupa makhluk hidup yang merupakan ciptaan Tuhan Yang Maha Esa yang sangat dekat dengan sikap spiritual. Siswa mempelajari Biologi hanya untuk sekedar dapat nilai ulangan atau ujian, sehingga cenderung hanya menghafal materi saja. Sikap spiritual siswa cenderung rendah, hal itu dapat dilihat dari kurang seriusnya siswa dalam berdoa, kurangnya penghargaan siswa terhadap ciptaan Tuhan YME berupa lingkungan seperti membuang sampah sembarangan, membunuh hewan tanpa sebab yang jelas, dan merusak tanaman.

Berdasarkan hasil pengamatan yang dilakukan di Madrasah Aliyah Ibnul qoyyim terkait pembelajaran di kelas, terdapat beberapa permasalahan yang diidentifikasi sebagai penyebab rendahnya sikap spiritual siswa, yakni pembelajaran biologi belum mengaitkan materi dengan nilai moral spiritual dalam agama. Pada Materi Ekosistem, guru hanya sekedar menyampaikan materi pembelajaran tanpa disertai nilai moral spiritual yang mendasari materi tersebut, padahal banyak bahasan dalam materi ini, misalnya konsep aliran energi, daur materi, interaksi antar organisme yang bisa dikaitkan dengan nilai moral spiritual yaitu bersyukur terhadap nikmat yang diberikan Tuhan YME, meyakini kekuasaan Tuhan YME, dan menghargai ciptaan Tuhan dan mengkaitkannya dengan lingkungan. Pembelajaran yang kurang menekankan pengembangan sikap moral spiritual tersebut menyebab- 
kan siswa hanya mendapatkan esensi materi pembelajaran secara parsial tidak utuh sampai ke bagian nilai moral spiritualnya. Dengan pembelajaran yang mengena sampai ke nilai moral spiritual, maka diharapkan siswa akan mempelajari biologi bukan hanya sekedar materi ilmiah, namun juga menyakini bahwa belajar biologi merupakan kewajiban bagi manusia sebagai ciptaan Tuhan YME. Selain itu dengan penanaman sikap spiritual dalam pembelajaran akan mendorong siswa untuk lebih menghargai ciptaan Tuhan YME dan mensyukuri semua nikmat yang telah diberikan Nya.

Ipgrave (2010, pp. 12-16) dalam penelitiannya menyatakan bahwa agama dan kepercayaan terhadap Tuhan YME akan memberikan arahan, alasan dan tujuan dalam proses pembelajaran sehingga akan menambah pengalaman dan pencapaian belajarnya. Selanjutnya penanaman sikap spiritual ini penting bagi siswa karena akan membentuk moral siswa ketika dewasa. Hal ini sesuai pendapat Cavanagh (1999, p. 198) yang menyatakan sikap spiritual yang dikembangkan di sekolah akan berimbas baik pada bisnis yang berarti sikap spiritual memungkinkan sesorang untuk memperoleh prespektif yang lebih baik dari perusahaannya, keluarga, tetangga, komunitas dan dirinya sendiri. Seseorang yang memiliki sikap spiritual akan berserah diri kepada Tuhan YME dan mengetahui bahwa kesuksesan bukan sematamata hasil usahanya saja hal ini akan mengurangi tingkat tekanan seseorang dan akan meningkatkan kualitas hidup.

Kondisi madrasah dengan basis pondok pesantren juga sama dengan madrasah pada umumnya. Madrasah dengan basis pondok pesantren juga memiliki keterbatasan waktu tatap muka di kelas, dikarenakan banyaknya jenis mata pelajaran yang harus diikuti baik pelajaran pondok pesantren maupun pelajaran umum. Mata pelajaran Biologi di kelas X memiliki jatah 3 Jam Tatap Muka (JTM) per minggu dari keseluruhan alokasi Jam Tatap Muka yang tersedia. Keterbatasan waktu tatap muka di kelas tersebut menjadi kendala untuk menyampaikan materi dengan metode konvensional, apalagi jika harus disertai dengan pengembangan sikap dan keterampilan. Dengan kondisi lingkungan belajar yang padat kegiatan, seharusnya siswa harus memiliki kemandirian tinggi dan mampu mengatur belajarnya. Seperti pendapat Mudjiman (2006, p. 7) yang menyatakan bahwa seseorang yang memiliki kemandirian dalam belajar memiliki ciri-ciri: (a) pembel- ajar aktif, terarah, dan kreatif untuk mencapai tujuan pembelajaran; (b) mempunyai motif atau niat menguasai suatu kompetensi; (c) pembelajar menetapkan sendiri tujuan belajar hingga evaluasinya, sehingga dia memegang kendali kegiatan belajarnya. Tapi kenyataan di lapangan siswa kurang terbiasa mandiri dalam belajar. Hal itu terlihat dari kebiasaan siswa yang tidak belajar jika tidak diminta oleh guru, dan kurang siap mengikuti pembelajaran di kelas.

Tujuan pembelajaran adalah mempersiapan peserta didik untuk menghadapi masa depannya. Dengan melatihkan kemandirian melalui pembelajaran, diharapkan siswa memiliki pengalaman belajar yang lebih banyak, sehingga dapat menjadi bekal kelak ketika dewasa. Dengan adanya jadwal yang padat dan pembelajaran kepesantrenan yang sarat dengan nilainilai Islam, keterbatasan waktu tatap muka, maka perlu dikembangkan bahan ajar yang dapat mengatasi kendala-kendala tersebut. Bahan ajar yang dikembangkan ini nantinya harus memiliki karakteristik bisa digunakan siswa secara mandiri, dapat digunakan sewaktuwaktu tidak terbatas pada jadwal pembelajaran di kelas, memuat materi pembelajaran dari suatu kompetensi atau sub kompetensi secara utuh, dan dapat memfasilitasi keunikan siswa sehingga siswa dapat belajar sesuai dengan kemampuan dan kecepatan belajarnya masingmasing.

Hingga saat ini bahan ajar yang dapat digunakan untuk mengembangkan sikap spiritual dan kemandirian siswa sekaligus masih jarang ditemukan. Padahal bahan ajar ini sangat diperlukan untuk mendukung tercapainya tujuan pembelajaran sesuai amanat kurikulum yang mencakup ranah pengetahuan, keterampilan dan sikap.

Bahan ajar menurut Sungkono, Wirasti, Suyanto, Sofyan, \& Karsimin (2009, p. 1) adalah suatu perangkat bahan yang memuat materi atau isi pembelajaran untuk mencapai tujuan pembelajaran dan dapat menarik perhatian siswa untuk belajar. Bahan ajar memiliki banyak macam dan jenis. Masing-masing bahan ajar tersebut memiliki kelebihan dan kekurangan, oleh karena itu dalam memilih bahan ajar perlu mempertimbangkan berbagai hal. Holden \& Westfall (2006, p. 9) menyebutkan bahwa pemilihan bahan ajar harus melalui evaluasi kriteria umum dan khusus, termasuk tujuan pembelajaran, karakteristik siswa, dan aspek biaya. 
Berdasarkan karakteristik bahan ajar yang ingin dikembangkan yaitu dapat digunakan oleh siswa secara mandiri, dapat digunakan sewaktuwaktu tidak terikat pada jam tatap muka di kelas, memuat materi pembelajaran secara utuh, dan memfasilitasi keunikan siswa dalam belajar, maka dipilih bahan ajar berbentuk modul yang berisi materi pembelajaran biologi bab ekosistem yang dipadukan dengan mapel berbasis pondok pesantren. Modul dipilih karena memiliki karakteristik disusun berdasarkan analisis kebutuhan pengguna, modul dapat digunakan untuk mengembangkan tujuan tertentu sesuai dengan analisis kebutuhan, modul dapat diintegrasikan dengan mapel agama berbasis pondok pesantren. Pemilihan materi ekosistem karena materi ini memiliki karakteristik dekat dengan alam dan sangat erat kaitannya dengan ciptaan Tuhan YME, sedangkan pemilihan mapel agama berbasis pondok pesantren untuk dipadukan dengan materi pembelajaran Biologi karena siswa madrasah sudah sangat akrab dengan materi keagamaan. Jika materi pembelajaran ekosistem disisipi atau dipadukan dengan mapel berbasis pondok pesantren, maka diharapkan penanaman sikap spiritual akan lebih mengena.

Bahan ajar Modul menurut Robinson \& Crittenden (1972, pp. 35-43)adalah bahan ajar yang disusun secara sistematis yang mencakup tujuan pembelajaran, isi materi, kegiatan pembelajaran, dan bahan evaluasi yang dapat digunakan secara mandiri. Penggunaan modul ini bertujuan untuk: pembelajaran individual, menciptakan pembelajaran konseptual yang meminimalisasi verbalistik guru, dan teknik instruksional, memungkinkan guru menganalisis proses pembelajaran, untuk meningkatkan pembelajaran dari hasil evaluasi terhadap outcome pembelajaran yang terukur.

Modul yang baik menurut Departemen Pendidikan Nasional (2008, pp. 4-5), memiliki karakteristik sebagai berikut (1). dapat dipelajari secara mandiri, artinya modul memuat tujuan dan kompetensi yang akan dicapai, memuat materi pembelajaran, memuat evaluasi, tugas, rangkuman, dan daftar pustaka; (2). memotivasi siswa, yang dapat diartikan bahwa modul menarik dari segi tampilan, proporsi/ukuran, penggunaan gambar, penggunaan bahasa yang sesuai EYD, konsistensi penggunaan bahasa, dan mudah digunakan; (3). Stand Alone (berdiri sendiri); yaitu modul yang dikembangkan tidak tergantung pada media lain atau tidak harus digunakan bersama-sama dengan media pembelajaran lain; (4). Self contained, artinya seluruh materi pembelajaran dari satu unit kompetensi atau sub kompetensi yang dipelajari terdapat di dalam satu modul secara utuh; (5). Adaptive, artinya materi modul mengikuti perkembangan ilmu pengetahuan dan teknologi, serta sesuai dengan tingkat perkembangan penggunanya; (7). Memuat rumusan tujuan pembelajaran/kompetensi dasar secara eksplisit; (8). Adanya evaluasi terhadap penguasaan siswa atas hasil belajarnya; (9). adanya reinforcement langsung terhadap respon siswa.

Keuntungan yang diperoleh dari pembelajaran dengan penerapan modul adalah sebagai berikut (Indriyanti \& Susilowati, 2010, p. 3). (1) Meningkatkan motivasi siswa, karena setiap kali mengerjakan tugas pelajaran yang dibatasi dengan jelas dan sesuai dengan kemampuan. (2) Setelah dilakukan evaluasi, guru dan siswa mengetahui benar, pada modul yang mana siswa telah berhasil dan pada bagian modul yang mana mereka belum berhasil. (3) Siswa mencapai hasil sesuai dengan kemampuannya. (4) Bahan pelajaran terbagi lebih merata dalam satu semester. (5) Pendidikan lebih berdaya guna, karena bahan pelajaran disusun menurut jenjang akademik.

Berdasarkan hal tersebut, modul Biologi berbasis aktivitas siswa di pondok pesantren ini diharapkan dapat digunakan untuk mengembangkan kemandirian karena dapat dipelajari siswa secara mandiri, dapat melatih siswa bertanggungjawab terhadap tugasnya. Modul ini juga diharapkan dapat menanamkan sikap spiritual karena dipadukan dengan mapel berbasis pondok pesantren yang sarat dengan nilai nilai islami, sekaligus mengembangkan kemampuan belajar kognitif siswa melalui materi Biologinya.

Tujuan penelitian ini adalah untuk mengetahui kelayakan modul Biologi yang disusun berbasis aktivitas siswa di pondok pesantren yang bisa melatih kemandirian siswa dalam belajar, dan memuat materi pembelajaran biologi yang dipadukan dengan materi-materi pembelajaran khas pondok pesantren sehingga dapat meningkatkan sikap spiritual siswa. Kelayakan modul Biologi berbasis aktivitas siswa di pondok pesantren ditinjau dari pemenuhan kriteria sebagai bahan ajar untuk menanamkan sikap spiritual, dan kemandirian siswa Madrasah Aliyah; mengetahui peningkatan sikap spiritual siswa setelah pembelajaran dengan modul Biologi berbasis pondok pesantren; mengetahui peningkatan sikap kemandirian 
siswa setelah pembelajaran dengan modul Biologi berbasis pondok pesantren.

\section{METODE}

Penelitian ini merupakan penelitian pengembangan atau Research and Development (R\&D) yang diadaptasi dari Borg \& Gall (1983). Penelitian dilaksanakan di MA Ibnul Qoyyim Sleman pada semester genap tahun pelajaran 2014/2015.

Subjek penelitian yang digunakan adalah dosen ahli, guru, teman sejawat, dan siswa. Uji coba modul skala kecil dilakukan pada lima siswa kelas X MA, sedangkan uji coba skala besar dilakukan pada 48 siswa kelas X MA Ibnul Qoyyim. Karena penelitian ini bertujuan mengembangkan modul biologi berbasis aktivitas siswa di pondok pesantren, pemilihan subyek siswa dilakukan dengan teknik purposive sampling untuk mendapatkan sampel siswa naracoba yang memiliki karakteristik siswa MA yang sekaligus sebagai santri yang tinggal dan mengikuti kegiatan di pondok pesantren.

Teknik yang digunakan dalam pengambilan data antara lain: (1) teknik dokumentasi, dilakukan untuk mendapatkan dokumentasi kegiatan selama penelitian berlangsung; (2) teknik quesioner/angket, quesioner pada penelitian ini berupa lembar validasi dan evaluasi modul yang digunakan untuk menilai kelayakan modul yang diisi oleh dosen ahli, guru, dan teman sejawat. Lembar angket keterbacaan dan lembar angket respon siswa untuk menilai kualitas modul yang diisi oleh siswa, Lembar angket penilaian diri sikap spiritual yang diisi oleh siswa untuk mengambil data keefektifan modul dalam meningkatkan sikap spiritual siswa, dan lembar angket penilaian diri kemandirian siswa untuk mengambil data keefektifan modul dalam meningkatkan kemandirian belajar siswa; (3) teknik observasi, digunakan untuk mendapatkan data tentang keefektifan modul dalam meningkatkan kemandirian belajar siswa. Lembar observasi ini digunakan untuk mencocokkan kemandirian siswa dari hasil isian angket.

\section{Prosedur}

Pengembangan modul Biologi berbasis pondok pesantren ini menggunakan model penelitian R \& D menurut Borg \& Gall (1983).

Penelitian ini dibatasi hanya sampai tahap ke tujuh dari sepuluh tahap pengembangan yang dikembangkan oleh Borg dan Gall. Tahapan yang dilakukan dalam penelitian ini adalah :
Research and Information collection (pencarian dan pengumpulan informasi), Planning (perencanaan), Develop Preliminary form of Product (pengembangan draft produk awal), Preliminary Field Testing (uji coba terbatas draft produk), Main Product Revision (revisi produk uji coba), Main Field Testing (uji lapangan produk utama), dan Operational Product Revision (revisi hasil uji lapangan produk utama). Sedangkan tahap operasional field testing, final product revision dan disemination tidak dilakukan dalam penelitian ini.

Tahap Research and Information colletion (pencarian dan pengumpulan informasi) meliputi kegiatan pengumpulan informasi melalui wawancara kepada guru Biologi, peserta didik kelas X, dan observasi terhadap proses pelaksanaan pembelajaran Biologi di kelas X semester I Tahun Ajaran 2014/2015. Pada tahap ini juga dilakukan analisis kebutuhan yang mencakup analisis kondisi belajar, analisis karakter siswa, analisis kurikulum dan instruksional, dan analisis materi.

Tahap Planning (perencanaan) bertujuan untuk menghasilkan prototipe perangkat pembelajaran. Langkah-langkah dalam tahap perencanaan ini adalah: pemilihan media/bahan ajar yang akan dikembangkan, pemilihan format dan desain modul, penyusunan instrumen pendukung penelitian.

Tahap Develop Preliminary form of Product (pengembangan draft produk awal), meliputi penentuan desain produk modul yang akan dikembangkan (desain hipotetik), penentuan sarana dan prasarana penelitian yang dibutuhkan selama proses penelitian dan pengembangan, penentuan tahap-tahap pelaksanaan uji desain di lapangan, dan penentuan deskripsi tugas pihak-pihak yang terlibat dalam penelitian. Termasuk di dalamnya antara lain pengembangan bahan pembelajaran, proses pembelajaran dan instrumen evaluasi.

Tahap Preliminary Field Testing (uji coba lapangan awal) merupakan uji produk secara terbatas, yaitu melakukan uji lapangan awal terhadap desain produk modul yang bersifat terbatas, baik substansi desain maupun pihakpihak yang terlibat. Uji lapangan awal dicobakan pada 5 orang siswa kelas $\mathrm{X}$ yang memiliki karakter mirip dengan siswa subjek penelitian untuk uji coba lapangan produk utama yaitu siswa MA yang sekaligus sebagai santri di pondok pesantren. Selama uji coba diadakan pengamatan, wawancara dan pengedaran angket. Pengumpulan data dengan kuesioner (angket) 
keterbacaan yang merupakan bentuk respon siswa terhadap modul. Dari tahap ini data yang dikumpulkan berupa data kualitatif yang diperoleh berupa komentar dan saran sebagai bahan revisi produk modul yang digunakan, juga data kuantitatif berupa lembar respon siswa rating scale skala 1-4 yang selanjutnya dianalisis.

Tahap Main Product Revision (revisi hasil uji coba lapangan awal) merupakan perbaikan model atau desain berdasarkan uji lapangan terbatas. Penyempurnaan produk awal akan dilakukan berdasarkan hasil evaluasi uji coba lapangan secara terbatas. Pada tahap penyempurnaan produk awal ini, lebih banyak dilakukan dengan pendekatan kualitatif. Saran yang diberikan oleh subyek coba pada uji coba lapangan awal dijadikan sebagai masukan untuk merevisi produk.

Tahap Main Field Testing (uji lapangan produk utama) merupakan uji produk dalam lingkup yang lebih luas, meliputi uji efektivitas desain produk, uji efektivitas desain ini menggunakan teknik eksperimen dengan desain pretest-postest control group design. Butir-butir pertanyaan dalam pretest dan posttest divalidasi isi dan validasi konstruk oleh ahli. Uji coba dilaksanakan di Madrasah Aliyah Ibnul Qoyyim dengan subjek penelitian siswa kelas X A dan X B.

Tahap Operational Product Revision (revisi produk) merupakan penyempurnaan produk modul berdasarkan masukan dan hasil uji lapangan utama. Masukan dari Jadi perbaikan ini merupakan perbaikan kedua setelah dilakukan uji lapangan yang lebih luas dari uji lapangan yang pertama. Selain perbaikan yang bersifat internal, penyempurnaan produk ini didasarkan pada evaluasi hasil sehingga pendekatan yang digunakan adalah pendekatan kuantitatif.

\section{Teknik Analisis Data}

Untuk data bersifat kualitatif yang telah diperoleh akan dianalisis dengan menggunakan rating scale. Dengan menggunakan rating scale, maka data mentah yang diperoleh berupa angka akan ditafsirkan menjadi kategori. Penyusunan instrumen dengan rating scale harus dapat mengartikan setiap angka yang diberikan pada alternatif jawaban pada setiap instrumen (Sugiyono, 2008, p. 141).

Teknik analisis data dilakukan dengan analisis deskriptif. Data yang dianalisis meliputi Analisis kelayakan modul dan respons peserta didik. Teknik analisis data untuk kelayakan modul dan respon peserta didik dilakukan dengan langkah-langkah berupa: (1) Tabulasi semua data yang diperoleh untuk setiap aspek penilaian, sub aspek dan butir penilaian modul dari setiap penilai; (2) Menghitung rerata skor dengan cara menghitung jumlah skor tiap aspek dibagi dengan jumlah validator; (3) Mengubah skor rata-rata menjadi nilai kategori.

Untuk mengetahui penilaian dan tanggapan dosen ahli dan guru Biologi terhadap produk modul Biologi berbasis pondok pesantren yang dikemas dalam bentuk bahan ajar tercetak dilakukan berdasarkan rating scale dengan skor 1, 2, 3,4, 5. Skor 1 artinya sangat kurang, skor 2 artinya kurang, skor 3 artinya cukup, skor 4 artinya baik, dan skor 5 artinya sangat baik.

Untuk mengetahui respon/tanggapan siswa terhadap produk modul Biologi berbasis pondok pesantren yang dikembangkan dilakukan berdasarkan rating scale dengan skor 1, 2, 3,4 . Skor 1 artinya tidak baik, skor 2 artinya cukup baik, skor 3 artinya baik, skor 4 artinya sangat baik.

Hasil analisis data yang diperoleh dari para ahli, praktisi, dan siswa digunakan untuk menentukan kevalidan produk yang dihasilkan dari segi teoritis dan kekonsistenan di antara komponen-komponen produk yang dikembangkan.

Tabel konversi dibuat dengan cara mengubah skor penilaian ahli, guru/praktisi, dan siswa menjadi nilai standar skala lima. Dalam hal ini peneliti menggunakan patokan yang diadaptasi dari Azwar (2010, p. 163) seperti disajikan pada Tabel 1.

Tabel 1. Konversi Data Kuantatif ke Kualitatif

\begin{tabular}{cc}
\hline Interval & Kriteria \\
\hline$M i+1,5 S B i<\mathrm{M}$ & Sangat baik \\
$M i+0,5 S B \mathrm{i}<\mathrm{M} \leq M i+1,5 \mathrm{SBi}$ & Baik \\
$M i-0,5 S B \mathrm{i}<\mathrm{M} \leq M i+0,5 \mathrm{SBi}$ & Cukup baik \\
$\mathrm{Mi}-1,5 \mathrm{SBi}<\mathrm{M} \leq M i-0,5 \mathrm{SBi}$ & Kurang baik \\
$\mathrm{M} \leq M i-1,5 \mathrm{Sbi}$ & Tidak baik \\
\hline
\end{tabular}

Keterangan:

$\mathrm{M}=$ Skor yang diperoleh

$M i=\frac{1}{2}($ skor maksimum ideal + skor minimum ideal $)$

$S B i=\frac{1}{6}($ skor maksimum ideal - skor minimum ideal $)$

Berdasarkan tabel konversi tersebut, maka dapat disusun kriteria penilaian modul berdasarkan aspek media, aspek materi, dan respon siswa terhadap modul yang tersaji pada Tabel 2, 3 dan 4. 
Tabel 2. Kriteria Penilaian Modul ditinjau dari Aspek Media

\begin{tabular}{cc}
\hline Interval skor & Kategori \\
\hline $\mathrm{x}>160$ & Sangat Baik \\
$133<\mathrm{x} \leq 160$ & Baik \\
$107<\mathrm{x} \leq 160$ & Cukup Baik \\
$80<\mathrm{x} \leq 107$ & Kurang Baik \\
$\mathrm{x} \leq 80$ & Tidak Baik \\
\hline
\end{tabular}

Tabel 3. Kriteria Penilaian Modul ditinjau dari Aspek Materi

\begin{tabular}{cc}
\hline Interval skor & Kategori \\
\hline $\mathrm{x}>124$ & Sangat Baik \\
$103<\mathrm{x} \leq 124$ & Baik \\
$83<\mathrm{x} \leq 103$ & Cukup Baik \\
$62<\mathrm{x} \leq 83$ & Kurang Baik \\
$\mathrm{x} \leq 62$ & Tidak Baik \\
\hline
\end{tabular}

Tabel 4. Kriteria Penilaian Respon Siswa terhadap Modul

\begin{tabular}{ccc}
\hline Interval skor & Nilai & Kategori \\
\hline $\mathrm{x}>78$ & $\mathrm{~A}$ & Sangat Baik \\
$66<\mathrm{x} \leq 78$ & $\mathrm{~B}$ & Baik \\
$54<\mathrm{x} \leq 66$ & $\mathrm{C}$ & Cukup Baik \\
$48<\mathrm{x} \leq 54$ & $\mathrm{D}$ & Kurang Baik \\
$\mathrm{x} \leq 48$ & $\mathrm{E}$ & Tidak baik \\
\hline
\end{tabular}

Berdasarkan kriteria tersebut, modul dinyatakan layak jika memperoleh penilaian minimal baik (B) pada setiap aspek dan mendapat respon minimal baik (B) pada keseluruhan aspek oleh siswa.

Untuk menilai sikap spiritual siswa digunakan angket penilaian diri sikap spiritual yang menilai aspek meyakini keberadaan Tuhan YME, menghargai ciptaan Tuhan YME dan mengaitkannya dengan lingkungan, serta bersyukur terhadap nikmat yang telah diberikan Tuhan. Penilaian dilakukan dengan rating scale dengan skala empat. Skor keseluruhan dijumlah dan dianalisis. Selanjutnya skor sikap spiritual sebelum penggunaan modul dan setelah penggunaan modul dihitung rerata dan gain score nya. Penghitungan gain score menggunakan rumus Hake (1998, p. 65), yaitu :

$$
\mathrm{g}=\frac{\text { postes-pretes }}{\text { skor maksimal-pretes }}
$$

selanjutnya nilai diinterpretasikan dengan kategori seperti pada Tabel 5.

Untuk mengetahui tingkat kemandirian siswa digunakan angket kemandirian siswa dan lembar observasi dengan rating scale dengan skala empat. Ada enam aspek yang menjadi aspek penilaian kemandirian belajar peserta didik, yaitu aspek motivasi belajar, pengguna- an sumber/ bahan ajar, cara belajar, tempo dan irama belajar, evaluasi hasil belajar, dan kemampuan refleksi. Selanjutnya skor dihitung persentasenya dengan cara membagi jumlah skor yang diperoleh dengan jumlah skor maksimal dikalikan dengan seratus persen.

Tabel 5. Kategori Nilai Gain Sikap Spiritual Siswa

\begin{tabular}{cc}
\hline Interval skor & Kategori \\
\hline$(\mathrm{N}-$ gain $) \geq 0,7$ & Tinggi \\
$0,7<(\mathrm{N}-$ gain $) \geq 0,3$ & Sedang \\
$(\mathrm{N}$-gain $)<0,3$ & Rendah \\
\hline
\end{tabular}

Selanjutnya persentase skor kemandirian diuji homogenitas dan normalitasnya. Jika data homogen dan berdistribusi normal selanjutnya di uji t untuk mengetahui efektifitas modul dalam meningkatkan kemandirian siswa. Tapi jika data tidak homogen dan tidak terdistribusi normal, maka dapat dilakukan uji non parametrik.

\section{HASIL DAN PEMBAHASAN}

\section{Hasil Pengembangan Produk}

Secara keseluruhan ada dua data pokok yang dihasilkan dalam penelitian ini, yaitu data kelayakan modul dan data pengaruh modul terhadap peningkatan sikap spiritual dan kemandirian siswa.

Uji kelayakan modul menggunakan instumen penilaian modul yang dijabarkan dari kriteria modul menurut Depdiknas (2008, pp.45), meliputi aspek materi dan media dengan indikator dapat dipelajari secara mandiri, self contained, stand Alone (berdiri sendiri, adaptive, memuat rumusan tujuan pembelajaran/kompetensi dasar secara eksplisit, merangsang motivasi siswa untuk berpartisipasi dalam pembelajaran, adanya reinforcement langsung terhadap respon siswa, adanya evaluasi terhadap penguasaan siswa atas hasil belajarnya, terintegrasi dengan materi dari mapel berbasis pondok pesantren.

Modul sebagai media pembelajaran layak digunakan karena berdasarkan hasil penilaian dosen ahli media mendapatkan skor 165 dari skor maksimal sebesar 200. Berdasarkan kriteria pada Tabel 2, maka modul memperoleh nilai A (kategori sangat baik) dengan catatan dan masukan untuk revisi. Skor 165 diperoleh dari kumulatif penilaian modul sebagai media dilihat dari aspek fisik/tampilan, kebahasaan, pemanfaatan, pendahuluan/petunjuk dalam modul, penugasan, dan rangkuman. Berdasarkan hasil penilaian tiap aspek, ada 4 aspek yang memper- 
oleh nilai sangat baik, yaitu aspek fisik/tampilan, aspek pemanfaatan, aspek penugasan, dan aspek rangkuman. Dua aspek yang mendapatkan nilai baik adalah aspek kebahasaan dan aspek pendahuluan/petunjuk. Berdasarkan penilaian masih ditemukan beberapa penulisan yang masih belum sesuai dengan kaidah penulisan yang benar, dan ada dua butir soal pada bagian uji kompetensi yang kurang sesuai dengan kisikisi. Saran dan masukan yang diberikan oleh validator ahli media dalam pengembangan modul adalah konsistensi penggunaan huruf kapital, konsistensi penggunaan numbering, kesesuaian uji kompetensi dengan kisi-kisi, penggunaan huruf kapital pada option (pilihan) dalam soal uji kompetensi.

Berdasarkan hasil penilaian dosen ahli materi, diperoleh skor 139 dengan skor maksimal 155, berdasarkan kriteria pada tabel 3 maka modul memperoleh nilai A (kategori sangat baik) dengan catatan dan masukan untuk revisi. Skor 139 diperoleh dari kumulatif penilaian aspek pendahuluan, pembelajaran, isi modul, penugasan, dan rangkuman yang keseluruhan dinilai amat baik. Berdasarkan penilaian masih ditemukan beberapa kesalahan dalam penulisan yang tidak sesuai EYD, penulisan peta konsep yang kurang lengkap, dan penggunaan gambar pada modul yang kurang jelas. Ada sebagian kegiatan belajar dalam modul yang belum mencantumkan soal uji kompetensi yang dikaitkan dengan sikap spiritual. Materi pembelajaran dalam modul ada yang kurang lengkap yaitu pada bagian interaksi antara komponen ekosistem yang seharusnya ada tiga yaitu interaksi antara komponen biotik-biotik, interaksi antara komponen biotik-abiotik dan interaksi antara komponen abiotik-abiotik, namun hanya disajikan dua komponen yaitu interaksi antara komponen biotik-biotik, dan interaksi antara komponen biotik-abiotik. Dari segi soal pada uji kompetensi, ditemukan satu butir soal yang kurang valid karena kurang sinkron antara soal dengan pilihan jawaban, dan satu butir soal yang pilihan jawabannya terlalu mudah. Berdasarkan hal tersebut, saran dan masukan yang diberikan oleh validator ahli materi adalah mengecek EYD, perbaikan peta konsep, memperbesar gambar agar lebih jelas, penambahan materi interaksi abiotik-abiotik dan daur sulfur, perbaikan soal uji kompetensi yang kurang valid, dan penambahan soal yang terkait dengan sikap spiritual.

Hasil penilaian aspek media dari guru Biologi diperoleh rerata skor sebesar 170,67.
Berdasarkan kriteria yang telah ditetapkan maka modul memperoleh nilai A (kategori sangat baik). Dari penilaian modul oleh guru ditemukan bahwa petunjuk penggunaan yang tertulis di dalam modul baru diberikan untuk siswa, yang seharusnya juga dilengkapi dengan petunjuk bagi guru karena pembelajaran tetap harus berlangsung dua arah dimana guru bertindak sebagai fasilitator. Dalam modul juga masih ada dua gambar yang belum diberikan judul dan sumber gambar, serta penggunaan ukuran font Arabic dalam penulisan kajian al Qur'an yang belum konsisten. Hasil penilaian aspek media dari teman sejawat diperoleh rerata skor sebesar 188. Berdasarkan kriteria yang telah ditetapkan maka rerata skor tesebut memperoleh nilai A (kategori sangat baik), namun masih ditemukan kekurangan yaitu masih ditemukan beberapa paragraf yang jaraknya tidak sama. Berdasarkan hasil penilaian dari guru dan teman sejawat maka modul dinyatakan layak dari aspek media dengan beberapa saran/masukan. Masukan dari guru dan teman sejawat adalah penambahan petunjuk penggunaan modul untuk guru, penulisan judul gambar dan sumbernya, konsistensi ukuran font Arabic dalam kajian Al qur'an, dan konsistensi jarak antar paragraf dalam modul.

Berdasarkan penilaian aspek materi yang dilakukan oleh guru Biologi diperoleh rerata skor 133,33 yang bernilai A (kategori sangat baik), sedangkan hasil penilaian teman sejawat memperoleh rerata skor sebesar 151,5 dengan nilai A (dengan kategori sangat baik), dengan demikian modul dinyatakan layak dari aspek materi. Saran dari guru/teman sejawat untuk aspek materi tidak ada.

Hasil evaluasi oleh guru Biologi dan teman sejawat terhadap modul baik dari aspek media maupun materi menunjukkan bahwa modul layak untuk diproduksi dan diujicobakan.

\section{Hasil Uji Coba Produk}

Hasil uji coba awal modul biologi berbasis aktivitas siswa di pondok pesantren diperoleh dari pengisian angket keterbacaan modul oleh siswa. Data keterbacaan modul oleh siswa disajikan dalam Tabel 6 .

Berdasarkan hasil uji keterbacaan modul oleh siswa memperoleh nilai A (sangat baik) pada semua aspek dengan masukan atau saran berupa penambahan glosarium dan warna cover modul agar lebih menarik. Berdasarkan hasil tersebut, modul yang disusun telah layak untuk digunakan. 
Jurnal Inovasi Pendidikan IPA, 4 (1), 2018 - 72

Nunung Susanti, D. Djukri

Tabel 6. Hasil Penilaian Uji Keterbacaan oleh Siswa

\begin{tabular}{clcccc}
\hline No. & \multicolumn{1}{c}{ Aspek } & Rerata Skor & Skor maksimal & Nilai & Kategori \\
\hline 1. & Materi & 17 & 20 & A & Sangat Baik \\
2. & Teks, bahasa, gambar & 17 & 20 & A & Sangat Baik \\
3. & Penyajian & 26,8 & 32 & A & Sangat Baik \\
4. & Kegrafisan & 19,8 & 24 & A & Sangat Baik \\
5. & Keseluruhan & 80,6 & 96 & A & Sangat Baik \\
\hline
\end{tabular}

Tabel 7. Hasil Respon Siswa terhadap Modul

\begin{tabular}{llcccc}
\hline No. & \multicolumn{1}{c}{ Aspek } & Rerata Skor & Skor maksimal & Nilai & Kategori \\
\hline 1. & Materi & 17,6 & 20 & A & Sangat Baik \\
2. & Teks, bahasa, gambar & 16,8 & 20 & A & Sangat Baik \\
3. & Penyajian & 29,2 & 32 & A & Sangat Baik \\
4. & Kegrafisan & 21,1 & 24 & A & Sangat Baik \\
5 & Keseluruhan & 84,61 & 96 & A & Sangat Baik \\
\hline
\end{tabular}

Tabel 8. Rerata Persentase Skor Kemandirian Belajar Siswa

\begin{tabular}{llccc}
\hline \multirow{2}{*}{ Kelas } & \multicolumn{2}{c}{ Rerata Persentase Kemandirian } & \multirow{2}{*}{ Gain Score } & \multirow{2}{*}{ Kategori } \\
\cline { 2 - 3 } & Sebelum pembelajaran & Setelah pembelajaran & & \\
\hline Kontrol & $73.49 \%$ & $72.49 \%$ & $-0,05$ & Rendah \\
Eksperimen & $71.89 \%$ & $86.49 \%$ & $+0,52$ & Sedang \\
\hline
\end{tabular}

Hasil uji lapangan produk modul biologi berbasis pondok pesantren dilihat dari: respon siswa berupa hasil penilaian modul oleh siswa, hasil uji coba pembelajaran biologi dengan modul yang dilihat dari sikap spiritual siswa, kemandirian siswa, dan hasil belajar siswa.

Hasil respon siswa terhadap modul dapat dilihat pada Tabel 7. Respon siswa terhadap modul adalah 84.61 dengan nilai A (predikat sangat baik) dengan komentar/masukan berupa: modul menarik dan membuat senang belajar, modul membuat siswa lebih mandiri dalam belajar Biologi, modul menarik karena dikaitkan dengan dalil dalil al Qur'an dan hadist, ukuran modul terlalu besar

Hasil pengukuran terhadap sikap spiritual siswa sebelum pembelajaran dengan modul memperoleh rerata skor sebesar 73,30, sedangkan setelah pembelajaran diperoleh rerata skor sebesar 78,75. Perhitungan dengan Hake's gain score diperoleh nilai sebesar 0,81 . Berdasarkan kategori, gain score berada pada kategori tinggi yang mengindikasikan bahwa modul efektif untuk meningkatkan sikap spiritual siswa.

Penggunaan modul biologi berbasis aktivitas siswa di pondok pesantren dalam pembelajaran dapat meningkatkan sikap spiritual siswa karena modul ini diintegrasikan dengan materimateri pelajaran berbasis pondok pesantren yang bernilai islam. Dengan adanya integrasi mapel pondok pesantren tersebut maka pemahaman siswa tidak hanya sebatas pemahaman tentang materi pelajaran umum namun sudah dikaitan dengan spiritual (kepercayaan) terhadap Tuhan Yang Maha Esa. Dengan demikian modul biologi berbasis pondok pesantren ini sekaligus berperan menciptakan lingkungan pembelajaran yang agamis sehingga merangsang siswa untuk senantiasa dekat dengan Tuhan Yang Maha Esa. Hal tersebut sesuai dengan pendapat Elmubarok (2008, pp. 32-36) yang menyatakan bahwa sikap spiritual merupakan akumulasi dari pengalaman penalaran yang kompleks, dan pembiasaan yang tidak bisa begitu saja muncul karena perlakuan tertentu, dan dalam prosesnya pembentukan moral/sikap spiritual ini sangat dipengaruhi oleh lingkungan baik lingkungan keluarga, sekolah, maupun masyarakat tempat seseorang tinggal.

Data hasil pengukuran kemandirian belajar siswa dapat dilihat dari perubahan persentase kemandirian siswa berdasarkan hasil observasi maupun hasil angket siswa yang disajikan dalam Tabel 8.

Berdasarkan Tabel 8 dapat diketahui bahwa pada kelas eksperimen (pembelajaran dengan modul) diperoleh gain score sebesar 0,52 yang berada pada kategori sedang. Berdasarkan hal tersebut dapat dikatakan bahwa modul memberi dampak pada perubahan kemandirian siswa.

Hasil uji homogenitas data kemandirian siswa pada kelas kontrol dan eksperimen menggunakan uji Lavene's dari SPSS, diperoleh nilai sig. $0,929(\mathrm{p}>0,05)$ yang berarti data kedua kelas homogen. Hasil Uji normalitas data kemandirian pada kelas kontrol dan eksprimen 
dengan uji Kolmogorov-Smirnov menunjukkan nilai sig. 0,062 dan $0,200(p>0,05)$, sedangkan dengan uji Shapiro-Wilk diperoleh nilai sig. $0,650$ dan 0,589 ( $>>0,05)$. Berdasarkan uji normalitas tersebut dapat dikatakan bahwa data terdistribusi normal. Karena data homogen dan berdistribusi normal, maka uji efektivitas modul untuk meningkatkan kemandirian belajar siswa juga dilakukan dengan menggunakan independent sample t-test.

Berdasarkan hasil uji $\mathrm{t}$ terhadap data kemandirian siswa diketahui bahwa nilai sig. 0,000 ( $\mathrm{P}<0,05)$ sehingga $\mathrm{H} 0$ ditolak dan $\mathrm{Ha}$ diterima yang berarti terdapat perbedaan rerata kemandirian belajar pada kelas yang kontrol maupun kelas eksperimen. Dengan demikian dapat dikatakan bahwa modul efektif untuk meningkatkan kemandirian siswa.

Hasil tersebut sesuai dengan hasil penelitian yang telah dilakukan oleh Shintania (2010) yang menyebutkan bahwa pembelajaran dengan modul pembelajaran terpadu mampu melatih kemandirian siswa dalam belajar, mampu menumbuhkan kemampuan siswa dalam bekerja sama, dan kinerja ilmiah. Begitu juga dengan hasil penelitian Evitasari (2012), yang menyimpulkan bahwa penggunaan modul meningkatkan kemandirian belajar dengan kategori sedang (gain score sebesar 0,49) dan ketuntasan kemandirian belajar sebesar $81,25 \%$.

Hal serupa juga dikuatkan oleh hasil penelitian Sekarini (2013) yang menyimpulkan bahwa kemandirian belajar peserta didik setelah menggunakan modul meningkat $2,36 \%$, (dengan angket) dan 20,47\% (dengan lembar observasi).

Kesuksesan pembelajaran dengan modul akan meningkatkan kemandirian belajar siswa, karena dengan belajar dengan modul managemen diri (self-management), monitoring diri (self monitoring), dan motivasi siswa akan terasah. Hal tersebut sesuai dengan pendapat Garrison (1997, pp. 21-29) yang menyatakan bahwa kemandirian belajar meliputi tiga dimensi yaitu: managemen diri (self-management), monitoring diri (self monitoring), dan motivasi. Jika seseorang telah mampu melaksanakan ketiga dimensi tersebut, maka dapat dikatakan bahwa ia telah mandiri dalam hal belajar.

\section{SIMPULAN DAN SARAN}

\section{Simpulan}

Berdasarkan hasil penelitian dan pengembangan dapat disimpulkan sebagai berikut: (1) Modul biologi berbasis pondok pesantren yang dikembangkan untuk menanamkan sikap spiritual dan kemandirian siswa dan dinyatakan dapat memenuhi kriteria sebagai bahan ajar. Hal ini berdasarkan penilaian dari validator ahli, guru biologi, dan teman sejawat, serta respon siswa terhadap modul yang secara keseluruhan mendapatkan nilai A (sangat baik). (2) Modul biologi berbasis pondok pesantren yang disusun meningkatkan sikap spiritual siswa secara signifikan. Hal tersebut ditunjukkan oleh nilai gain score 0,81 dengan kategori peningkatan sikap spiritual tinggi. (3) Modul biologi berbasis pondok pesantren yang disusun dapat meningkatkan kemandirian siswa dalam belajar. Hal tersebut dibuktikan dari gain score kelas eksperimen sebesar 0,52, yang menunjukkan perubahan kemandirian siswa dengan kategori sedang, serta hasil uji t dengan nilai sig. $0,000(\mathrm{p}<0,05)$ yang menunjukkan bahwa ada perbedaan rerata kemandirian pada kelas kontrol dan kelas eksperimen.

\section{Saran}

Saran pemanfaatan produk berupa Modul biologi berbasis aktivitas siswa di pondok pesantren pada materi ekosistem dapat dimanfaatkan secara maksimal oleh pendidik. Produk dapat digunakan sebagai alternatif pembelajaran biologi untuk meningkatkan sikap spiritual dan kemandirian siswa. Penanaman sikap spiritual dan kemandirian sebaiknya juga tidak hanya dari modul saja, tetapi dilatihkan dan dicontohkan pada kegiatan pembelajaran yang lain agar hasil yang diperoleh maksimal.

\section{DAFTAR PUSTAKA}

Azwar, S. (2010). Tes prestasi: Fungsi dan pengembangan pengukuran prestasi belajar. Yogyakarta: Pustaka Belajar.

Borg, W. R., \& Gall, M. D. (1983). Educational research: An introduction. New York: Longman.

Cavanagh, G. F. (1999). Spirituality for managers: Context and critique. Journal of Organizational Change Management, 12(3), 186-199. https://doi.org/10.1108/095348199102737 93

Chiappetta, E. L., \& Koballa, T. R. (2010). Science instruction in the middle and secondary schools: Developing fundamental knowledge and skills. New York: Allyn \& Bacon.

Crawford, M., \& Rossiter, G. (1991). Teaching 
wisdom: Religious education and the moral and spiritual development of young people. Journal of Christian Education, os-34(2), 47-63. https://doi.org/10.1177/002196579103400 206

Departemen Pendidikan Nasional. (2008). Penulisan modul. Jakarta: Direktorat Tenaga Kependidikan Direktorat Jenderal Peningkatan Mutu Pendidikan dan Tenaga Kependidikan Depdiknas.

Elmubarok, Z. (2008). Membumikan pendidikan nilai. Bandung: Alfabeta.

Evitasari, A. D. (2012, September 29). pengembangan bahan ajar berbasis modul pada materi pencemaran lingkungan untuk meningkatkan kemandirian dan hasil belajar siswa kelas X SMA Negeri 2 Wates Kulon Progo. Universitas Negeri Yogyakarta. Retrieved from http://eprints.uny.ac.id/36036/

Garrison, D. R. (1997). Self-directed learning: toward a comprehensive model. Adult Education Quarterly, 48(1), 18-33. https://doi.org/10.1177/074171369704800 103

Hake, R. R. (1998). Interactive-engagement versus traditional methods: A sixthousand-student survey of mechanics test data for introductory physics courses. American Journal of Physics, 66(1), 6474. https://doi.org/10.1119/1.18809

Holden, J. T., \& Westfall, P. J.-L. (2006). An instructional media selection guide for distance learning. Missouri: United States Distance Learning Association.

Indriyanti, N. Y., \& Susilowati, E. (2010). Pengembangan modul. Surakarta. Retrieved from http://nurma.staff.uns.ac.id/files/2010/08/t eori-pengembangan-modul.doc.

Ipgrave, J. (2010). Including the religious viewpoints and experiences of muslim students in an environment that is both plural and secular. Journal of International Migration and Integration / Revue de L'integration et de La Migration Internationale, 11(1), 5-22. https://doi.org/10.1007/s12134-009-01286

Mudjiman, H. (2006). Belajar mandiri. Surakarta: UNS Press. Surakarta.

Robinson, J. W., \& Crittenden, W. B. (1972). Learning modules: A concept for extension educators? Journal of Extension, 10, 35-42. Retrieved from https://www.joe.org/joe/1972winter/19724-a3.pdf

Sekarini, R. P. (2013). Pengembangan modul IPA terpadu berbasis paikem dengan tema "Sains dalam proses tatah sungging wayang kulit" untuk meningkatkan kemandirian peserta didik SMP kelas VIII. Universitas Negeri Yogyakarta.

Sugiarto, A., \& Djukri, D. (2015). Pembelajaran berbasis SETS sebagai upaya meningkatkan kreativitas dalam pemecahan masalah pencemaran lingkungan. Jurnal Inovasi Pendidikan IPA, $1(1), \quad 1-11$. https://doi.org/10.21831/jipi.v1i1.4527

Sugiyono, S. (2008). Metode penelitian pendidikan: (pendekatan kuantitatif, kualitatif dan $R \& D$ ). Bandung: Alfabeta.

Sungkono, D. S., Wirasti, M. K., Suyanto, S., Sofyan, H., \& Karsimin, A. (2009). Pengembangan Bahan Ajar. Yogyakarta: Universitas Negeri Yogyakarta. 